\title{
The Analysis of Long-Term Trends in the Meteorological and Hydrological Drought Occurrences Using Non-Parametric Methods-Case Study of the Catchment of the Upper Noteć River (Central Poland)
}

\author{
Katarzyna Kubiak-Wójcicka ${ }^{1,2, *(\mathbb{D})}$, Agnieszka Pilarska ${ }^{1}$ and Dariusz Kamiński ${ }^{3,4}$ (D) \\ 1 Faculty of Earth Sciences and Spatial Management, Nicolaus Copernicus University, Lwowska 1, \\ 87-100 Toruń, Poland; apilarska@umk.pl \\ 2 Centre for Underwater Archaeology, Nicolaus Copernicus University, Lwowska 1, 87-100 Toruń, Poland \\ 3 Faculty of Biological and Veterinary Sciences, Nicolaus Copernicus University, Lwowska 1, \\ 87-100 Toruń, Poland; daro@umk.pl \\ 4 Centre for Climate Change Research, Nicolaus Copernicus University, Lwowska 1, 87-100 Toruń, Poland \\ * Correspondence: kubiak@umk.pl
}

check for updates

Citation: Kubiak-Wójcicka, K.; Pilarska, A.; Kamiński, D. The Analysis of Long-Term Trends in the Meteorological and Hydrological Drought Occurrences Using Non-Parametric Methods-Case Study of the Catchment of the Upper Noteć River (Central Poland). Atmosphere 2021, 12, 1098. https://doi.org/10.3390/ atmos12091098

Academic Editors: Andrzej Walega and Agnieszka Ziernicka-Wojtaszek

Received: 16 July 2021

Accepted: 20 August 2021

Published: 25 August 2021

Publisher's Note: MDPI stays neutral with regard to jurisdictional claims in published maps and institutional affiliations.

Copyright: (c) 2021 by the authors. Licensee MDPI, Basel, Switzerland. This article is an open access article distributed under the terms and conditions of the Creative Commons Attribution (CC BY) license (https:// creativecommons.org/licenses/by/ $4.0 /)$.

\begin{abstract}
The study aims to identify long-term trends in the changes of drought occurrences using the Mann-Kendall (MK) test and the Theil-Sen estimator. Trend research was carried out on the example of the catchment area of the Upper Noteć River, which covers an agricultural area of Poland with some of the lowest water reserves. The meteorological droughts were identified based on the Standardized Precipitation Index (SPI), while the hydrological droughts were determined on the basis of the Standardized Runoff Index (SRI) in various time scales (1, 3, 6, 9 and 12 months) in the period of 1981-2016. The relationship between SPI and SRI was determined on the basis of the Pearson correlation analysis. The results showed that statistically significant trends (at the significance level of 0.05 ) were identified at 3 out of 8 meteorological stations (downward trend at Kłodawa station and upward trend for drought at Sompolno and Kołuda Wielka stations). Statistically significant hydrological droughts showed an increase in occurrences at the Łysek station, while a downward trend was noted at the Noć Kalina station. No trend was found at the Pakość station. The analysis of the correlation between meteorological and hydrological droughts showed a strong relationship in dry years. The maximum correlation coefficient was identified in longer accumulation periods i.e., 6 and 9 months. The example of the catchment of the Upper Noteć River points to the necessity of using several indicators in order to assess the actual condition of the water reserves.
\end{abstract}

Keywords: meteorological drought; hydrological drought; trends; central Poland

\section{Introduction}

Drought is a natural disaster characterized by long-term water scarcity [1-3]. Drought is one of the most serious natural threats that causes damage to various aspects of the environment, society, and economy [4,5]. No universal definition of drought has been established due to the wide variability in water supply and demand worldwide [6,7]. There are four categories of drought in the literature: meteorological, agricultural, hydrological, and socioeconomic [8-13]. Drought damage is a serious issue in numerous countries around the world. Due to its nature, drought is difficult to monitor, and its effects are often poorly documented. Among the various sectors of the economy, agriculture is one of the most vulnerable to drought, where its effects are also most noticeable [14-16]. Numerous reports and scientific articles indicate that forecasts of future climate conditions suggest an increase in the frequency and intensity of droughts in some regions of the world [17-21]. The increase in the frequency of drought occurrence in recent years has not been limited to arid and semi-arid regions [22-26], but has been gradually becoming more common in 
regions with a temperate and humid climate [27-32]. Poland, which has one of the most limited water resources in Europe [33], is among those regions experiencing an increase in drought frequency [34]. The distribution of water resources in Poland has been diversified in terms of time and space. In the current climate, many regions of the country often suffer from water scarcity. In the future, this scarcity may become even more serious, and the availability of water resources might become limited. In recent years, only slight changes in annual precipitation totals have been recorded in Poland, however a noticeable shift has been observed in seasonal and monthly precipitation distribution [35,36]. Moreover, there have been quite significant changes in thermal conditions, characterized by a great increase in air temperature over a multi-year period [37]. As a result of these changes, temporary difficulties in water supply have been recorded in some areas of Poland [38]. This problem will be particularly harmful for the agricultural regions of the country. Polish agriculture is largely dependent on precipitation, which is highly variable both in terms of its temporal and spatial characteristics. Plant production is reliant mainly on water obtained from precipitation and available to plants by means of water-retentive soil [39]. In the event of a drought in agricultural areas, crop irrigation is required, especially during the growing season [40].

Drought studies in Poland have been conducted at a regional and local level. Previously published drought analyses mainly refer to the classification of drought types using various drought indicators [41-43], monitoring of drought conditions [44-47], as well as the characteristics of the drought, including its duration, intensity, size and frequency [48].

This study focuses on the research of drought trends in the period of 1981-2016, in a particularly drought-susceptible area of Poland. The analysis of drought trends in the long term might indicate the direction of possible near-future changes. The case study focuses on the catchment of the Upper Noteć River, which is a heavily exploited agricultural area with some of the lowest reserves of water.

The main objectives of this study included:

(1) the identification of meteorological droughts based on SPI indicators, and hydrological droughts based on SRI indicators in various time scales (1, 3, 6, 9 and 12 months)

(2) trend determination using the Mann-Kendall (MK) test and Theil-Sen estimator

(3) the determination of a relationship between SPI and SRI by means of Pearson's correlation analysis.

The obtained results will help the departments of state administration, responsible for water resources management, make informed decisions and establish a long-term local development strategy, regulating the sustainable management of water resources.

\section{Materials and Methods}

\subsection{Study Area and Dataset}

The research was carried out in Poland, a region located in a temperate climate zone with a predominance of polar-sea air masses. The amount of precipitation in Poland varies temporally and spatially. The average annual precipitation in Poland recorded in the period of 1981-2010 was $603 \mathrm{~mm}$. The lowest annual precipitation total of $500 \mathrm{~mm}$ was observed in the central part of the country, and the highest $-970 \mathrm{~mm}$, in the south of Poland [49]. The area covered by the analysis includes the Upper Noteć catchment, closed by the water gauge in Pakość (Figure 1). The catchment area up to the Pakość station is $2301.98 \mathrm{~km}^{2}$. This catchment is located in the historical region of Kujawy, which is extremely important for agriculture. Arable land within the catchment area accounts for $76.07 \%$ of the catchment area, while forest areas account for $11.4 \%$. It is also the region with the lowest annual precipitation in Poland and the area with the highest water shortages in agriculture [50]. 

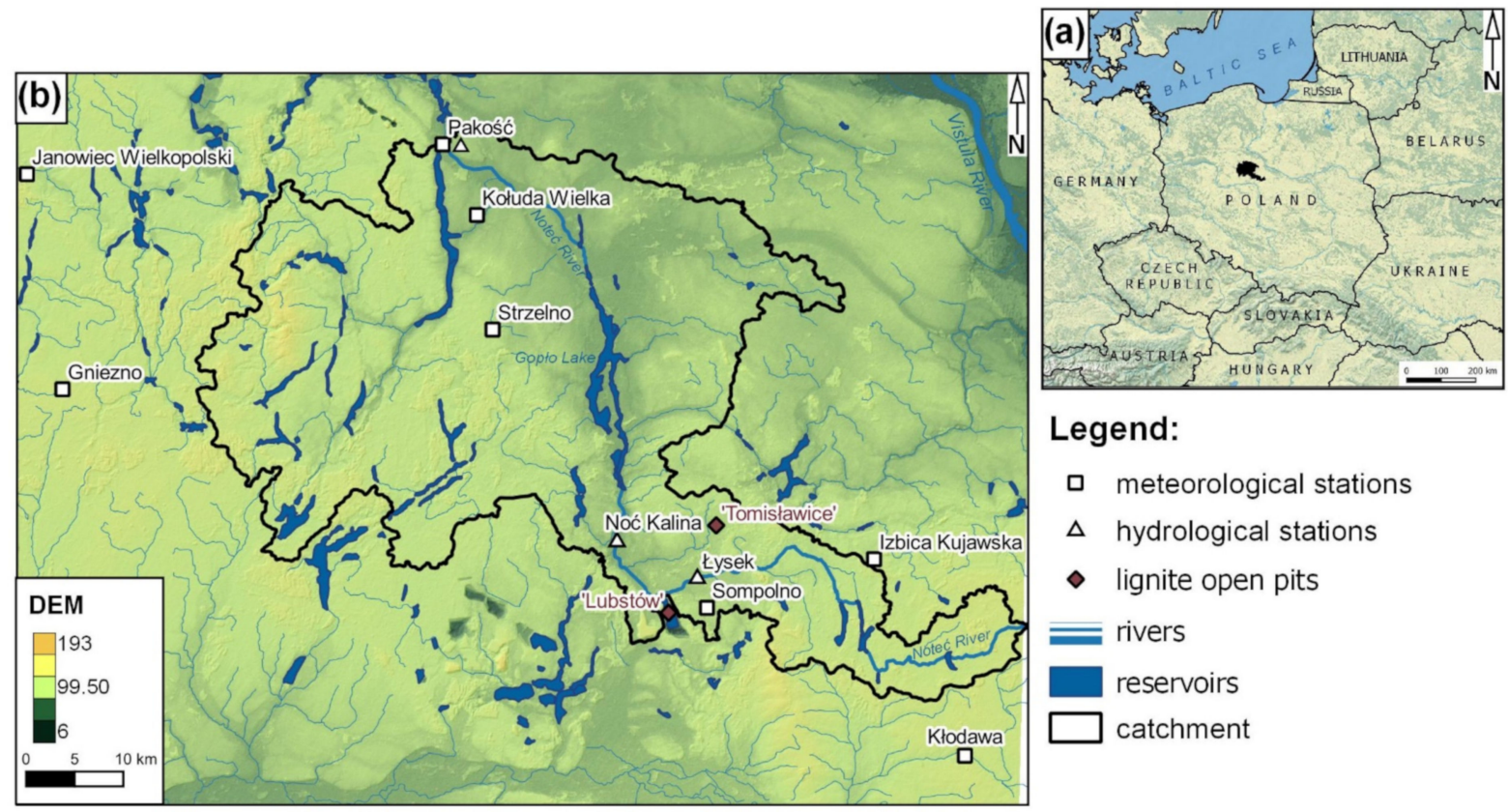

\section{Legend:}

- meteorological stations

$\Delta$ hydrological stations

$\diamond \quad$ lignite open pits

ivers

reservoirs

$\square$ catchment

Figure 1. Study area. Source: (a) own elaboration made with [51,52]. Map elaborated in the coordinate system: WGS 84/UTM zone 34N; (b) own elaboration made with [52-54], location of the stations based on [55,56] and Table 1, location of the lignite open pits based on [56,57]. Meteorological station Izbica Kujawska is out of catchment area according to coordinates from Table 1. Location of the hydrological station Pakość is determined by cartographic issues. Map elaborated in the coordinate system: WGS 84 /UTM zone $34 \mathrm{~N}$.

Table 1. Annual sum of atmospheric precipitation in the period of 1980-2016.

\begin{tabular}{|c|c|c|c|c|c|c|}
\hline \multirow{2}{*}{ Meteorological Station } & \multirow{2}{*}{$\begin{array}{l}\text { Altitude } \\
\text { (m a.s.1.) }\end{array}$} & \multirow{2}{*}{ Latitude } & \multirow{2}{*}{ Longitude } & \multicolumn{3}{|c|}{ Total Precipitation during the Year (mm) } \\
\hline & & & & Average & Maximum/Year & Minimum/Year \\
\hline Izbica Kujawska & 120 & $52^{\circ} 26^{\prime} \mathrm{N}$ & $18^{\circ} 46^{\prime} \mathrm{E}$ & 529.3 & $817.6 / 2010$ & $309.6 / 2011$ \\
\hline Pakość & 75 & $52^{\circ} 48^{\prime} \mathrm{N}$ & $18^{\circ} 05^{\prime} \mathrm{E}$ & 513.5 & $704.1 / 2010$ & $291.4 / 1989$ \\
\hline Kołuda Wielka & 85 & $52^{\circ} 44^{\prime} \mathrm{N}$ & $18^{\circ} 09^{\prime} \mathrm{E}$ & 500.1 & $810.7 / 1980$ & $212.5 / 1989$ \\
\hline Strzelno & 105 & $52^{\circ} 38^{\prime} \mathrm{N}$ & $18^{\circ} 11^{\prime} \mathrm{E}$ & 542.5 & $816.9 / 1980$ & $246.6 / 1989$ \\
\hline Sompolno & 96 & $52^{\circ} 23^{\prime} \mathrm{N}$ & $18^{\circ} 31^{\prime} \mathrm{E}$ & 516.0 & $847.6 / 2010$ & $302.7 / 1989$ \\
\hline Gniezno & 124 & $52^{\circ} 33^{\prime} \mathrm{N}$ & $17^{\circ} 34^{\prime} \mathrm{E}$ & 506.6 & $708.5 / 2010$ & $282.2 / 1982$ \\
\hline Janowiec Wielkopolski & 95 & $52^{\circ} 46^{\prime} \mathrm{N}$ & $17^{\circ} 29^{\prime} \mathrm{E}$ & 519.6 & $760.2 / 2010$ & $275.5 / 1982$ \\
\hline Kłodawa & 120 & $52^{\circ} 15^{\prime} \mathrm{N}$ & $18^{\circ} 55^{\prime} \mathrm{E}$ & 531.2 & $763.2 / 2001$ & $306.4 / 1989$ \\
\hline
\end{tabular}

The data used in this work are derived from historical series of daily precipitation totals recorded at 8 meteorological stations (Izbica Kujawska, Kołuda Wielka, Pakość, Sompolno, Strzelno, Gniezno, Janowiec Wielkopolski, Kłodawa). Air temperature measurements were obtained from the Kołuda Wielka station. Discharge data were obtained from 3 hydrological stations: Łysek, Noć Kalina and Pakość. Meteorological and hydrological data for the period of 1980-2016 were obtained from the Institute of Meteorology and Water Management-National Research Institute. Daily values were converted into monthly values for the purpose of extended calculations.

In terms of annual precipitation, the Upper Noteć area is one of the regions with the lowest precipitation in Poland. Total annual precipitation in the period of 1980-2016 ranged from $500.1 \mathrm{~mm}$ (Kołuda Wielka) to $542.5 \mathrm{~mm}$ (Strzelno) (Table 1). The highest precipitation totals were recorded in 2010 at most meteorological stations. The exceptions were Kłodawa, with the maximum precipitation occurring in 2001, and Kołuda Wielka and Strzelno, with the maximum recorded precipitation in 1980. The lowest precipitation totals were recorded at most stations in 1989, with the exception of the stations in Gniezno and Janowiec, where the lowest annual precipitation were recorded in 1982, and Izbica Kujawska, where the 
lowest totals occurred in 2011. Air temperature measurements were carried out only at the meteorological station in Kołuda Wielka. The average annual air temperature at the meteorological station in Kołuda Wielka in $1980-2016$ was $8.5^{\circ} \mathrm{C}$, and the highest average annual air temperature was recorded in $1989\left(9.8^{\circ} \mathrm{C}\right)$ (Figure 2).

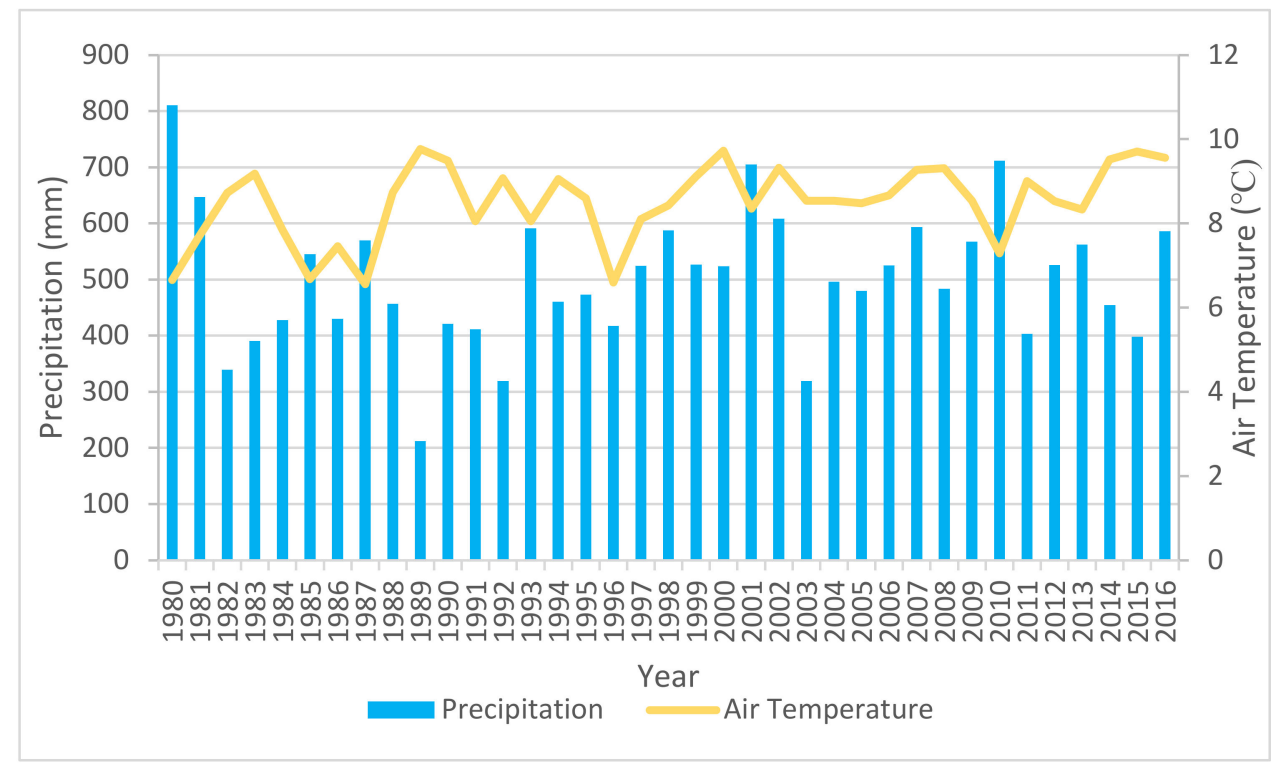

Figure 2. Average annual air temperature and average precipitation sums at the Kołuda Wielka meteorological station in the period of 1980-2016.

In terms of hydrology, the catchment area of the Upper Noteć is categorised as one of the areas with the most limited water resources [58]. According to Tomaszewski and Kubiak-Wójcicka [59], the average long-term unit runoff of the Noteć measured at the Pakość water gauge in the period of 1951-2015 amounted to $2.41 \mathrm{dm}^{3} \cdot \mathrm{s}^{-1} \cdot \mathrm{km}^{-2}$. This is the lowest unit runoff value recorded in Poland, with an average of $5.5 \mathrm{dm}^{3} \cdot \mathrm{s}^{-1} \cdot \mathrm{km}^{-2}$ [34]. Both precipitation and discharge in the catchment area of the Upper Noteć River are among the lowest in Poland. During the analysed period of 1980-2016, the unit runoff of the Notec River at the Pakość station was $2.21 \mathrm{dm}^{3} \cdot \mathrm{s}^{-1} \cdot \mathrm{km}^{-2}$. The highest values of the maximum discharge were recorded in July 1980 at all hydrological stations. The maximum discharge at the Pakość station was $69.3 \mathrm{~m}^{3} \cdot \mathrm{s}^{-1}$ (unit runoff $30.1 \mathrm{dm}^{3} \cdot \mathrm{s}^{-1} \cdot \mathrm{km}^{-2}$ ), and the lowest discharge was recorded in October $2003\left(0.23 \mathrm{dm}^{3} \cdot \mathrm{s}^{-1} \cdot \mathrm{km}^{-2}\right)$ (Table 2). At the Noć Kalina station, the lowest discharge was recorded in September 1989 and August 1992. However, the lowest discharge at the Eysek station was recorded from August to December 2015 and in January 2016, at which time virtually no discharge occurred in the watercourse bed.

Table 2. Hydrological characteristics of the Noteć River in the period of 1980-2016-annual discharge.

\begin{tabular}{ccccc}
\hline $\begin{array}{c}\text { Hydrological } \\
\text { Station }\end{array}$ & $\begin{array}{c}\text { The Catchment } \\
\text { Area } \mathbf{( \mathbf { k m } ^ { 2 } )}\end{array}$ & $\begin{array}{c}\text { Average } \\
\text { Multi-Year } \\
\text { Discharge } \\
\left(\mathbf{m}^{\mathbf{3}} \cdot \mathbf{s}^{-\mathbf{1})}\right.\end{array}$ & $\begin{array}{c}\text { Maximum } \\
\text { Discharge } \\
\left(\mathbf{m}^{\mathbf{3}} \cdot \mathbf{s}^{-\mathbf{1}}\right)\end{array}$ & $\begin{array}{c}\text { Minimum } \\
\text { Discharge } \\
\left(\mathbf{m}^{\mathbf{3}} \cdot \mathbf{s}^{-\mathbf{1}} \mathbf{)}\right.\end{array}$ \\
\hline Łysek & 303.32 & 0.74 & 10.7 & 0.001 \\
Noć Kalina & 426.11 & 1.47 & 16.7 & 0.05 \\
Pakość & 2301.98 & 5.08 & 69.3 & 0.53 \\
\hline
\end{tabular}

\subsection{Standardized Precipitation Index (SPI) and Standardized Runoff Index (SRI)}

Two indicators were used to determine droughts: the Standardized Precipitation Index (SPI), which defines meteorological droughts, and the Standardized Runoff Index (SRI), which defines hydrological droughts. Data from 8 meteorological stations: 5 located 
within the catchment area of the Noteć River (Pakość, Strzelno, Sompolno, Izbica Kujawska, Kołuda Wielka) and 3 in its close vicinity (Kłodawa, Gniezno and Janowiec Wielkopolski) were used to determine meteorological droughts.

The Standardized Precipitation Index (SPI) is one of the most frequently used indicators of a meteorological drought, and was developed on the basis of the normalization of precipitation probabilities [60]. This indicator defines a precipitation deficit and allows the monitoring of droughts in different time frames. The SPI is recommended by the World Meteorological Organisation (WMO) for determining the phenomenon of drought [61]. For more information on the formulation of SPI, its advantages and limitations, see papers [62-64].

The SPI was calculated on the basis of monthly precipitation totals for 5 meteorological stations in the upper catchment area of the Noteć River (Izbica Kujawska, Strzelno, Kołuda Wielka, Sompolno and Pakość) and 3 stations in its close vicinity (Kłodawa, Gniezno and Janowiec Wielkopolski). The daily precipitation data were aggregated into monthly time scales, and fitted to a two-parameter gamma distribution function. The SPI was calculated for each month at different timescales. Therefore, 5 different time series were analysed, i.e., 1-, 3-, 6-, 9- and 12-months. SPI values define the deviation from the median expressed in units of standard deviation, which was calculated according to the formula:

$$
S P I, S R I=\frac{f(x)-u}{\sigma}
$$

SPI, SRI-Standardized Precipitation Index, Standardized Runoff Index

$f(x)$-transformed sum of precipitation, discharges

$\mu$-mean value of the normalized index $x$

$\sigma$-standard deviation of index $x$

In order to calculate the SPI, the compliance of the distribution of the transformed variable $f(P)$ with the normality distribution was tested using the $x^{2}$-Pearson normality test [65].

The Standardized Runoff Index (SRI) is calculated according to the same procedure as the SPI, however it is based on the discharge data [66-69]. A 2-parameter logarithmic function was used as a normalizing function when calculating the SRI [70]. The detailed calculation method is presented in the study $[9,47]$. The probabilities were transformed into standard normal distribution. The application of SPI allows for the differentiation of the intensity of a drought using a set of SPI thresholds: $-1,-1.5,-2$ and 1.0, 1.5, 2 for moderate, severe and extreme droughts and precipitations, respectively [28].

The proposed approach is based on the assessment of water resources under different hydroclimatic conditions and the determination of different intensity classes. The adoption of standardized indicators allowed for the classification of drought intensity, which is presented in Table 3. Extreme events were identified for the indicator values above 1.0, when rainy periods occur, and for the indicator values below -1.0 , when there are droughts.

Table 3. The classification scale for SPI and SRI values.

\begin{tabular}{cc}
\hline SPI, SRI Value & Category \\
\hline SPI $/$ SRI $\geq 2.0$ & Extremely wet \\
$2.0>$ SPI $/$ SRI $\geq 1.5$ & Severely wet \\
$1.5>$ SPI SRI $\geq 1.0$ & Moderately wet \\
$1.0>$ SPI $/$ SRI $>-1.0$ & Normal \\
$-1.0 \geq$ SPI $/$ SRI $>-1.5$ & Moderately dry \\
$-1.5 \geq$ SPI $/$ SRI $>-2.0$ & Severely dry \\
SPI $/$ SRI $\leq-2.0$ & Extremely dry \\
\hline
\end{tabular}




\subsection{Mann-Kendall Test}

The Mann-Kendall test [71,72] is a non-parametric statistical method used to determine whether a time series has a monotonic upward or a downward trend. It is a rank-based procedure that is particularly suitable for data with abnormal distribution that contain outliers and non-linear trends [73].

The Mann-Kendall $S$ statistic is described with the Formula (2):

$$
\begin{gathered}
S=\sum_{k=1}^{n-1} \sum_{j=k+1}^{n} \operatorname{sgn}\left(x_{j}-x_{k}\right) \\
\operatorname{sgn}\left(x_{j}-x_{k}\right)=\left\{\begin{array}{c}
+1 \text { if }\left(x_{j}-x_{k}\right)>0 \\
0 \text { if }\left(x_{j}-x_{k}\right)=0 \\
-1 \text { if }\left(x_{j}-x_{k}\right)<0
\end{array}\right.
\end{gathered}
$$

where:

$x_{j}$ and $x_{k}$-values of the variable in individual years $j$ and $k$, where $j>k$,

$n$-the series count (number of years).

Positive " $S$ " values represent an upward trend, while negative values indicate a downward one. The calculation of "sgn $\left(x_{j}-x_{k}\right)$ " is done via Equation (3).

The $S$ statistic shows a tendency to quickly move towards normality, and for $n>10$ this statistic has an approximately normal distribution with the mean of 0 and the variance described by the Formula (4):

$$
\operatorname{Var}(S)=[n(n-1)(2 n+5)] / 18
$$

The normalized $Z$ test statistic is determined by the Formula (5):

$$
Z=\left\{\begin{array}{l}
\frac{S-1}{\sqrt{\operatorname{Var}(S)}} \text { if } S>0 \\
0 \text { if } S=0 \\
\frac{S+1}{\sqrt{\operatorname{Var}(S)}} \text { if } S<0
\end{array}\right.
$$

In the Mann-Kendall test, the null hypothesis is that there is no significant trend in the data series. The trend is significant if the null hypothesis cannot be accepted. The acceptance region at the significance level of $\alpha=0.05$ is defined by the range of $-1.96 \leq Z \leq 1.96$ (no significant trend), while the rejection region was determined by $Z<-1.96$ (significant downward trend) and $Z>1.96$ (significant upward trend), where $Z$ is the normalized test statistic [47].

The non-parametric Mann-Kendall test is commonly used to quantify trends in hydrometeorological time series [74,75], despite some limitations [76-79].

\subsection{Sen's Slope}

The Mann-Kendall test is an effective method of identifying trends in a time series, but does not indicate the magnitude of the trends. The test might be supplemented with a non-parametric Sen's method. In order to estimate the actual slope of the existing trend, the non-parametric Sen's method was used [80]. The main advantage of the Sen's slope estimator is its resistance to the presence of extreme values [81].

The slope $\beta$ expressed by the Theil-Sen estimator $(\beta)$ is described by the Formula (6):

$$
\beta=\operatorname{Median}\left(\left(x_{j}-x_{k}\right) /(j-k)\right)
$$

A positive value of $\beta$ indicates an upward (increasing) trend, and a negative value indicates a downward (decreasing) trend in the time series.

The Mann-Kendall test and Theil-Sen estimator were performed by means of a RStudio [82] with packages: "readxl" [83] and "trend" [84]. Information about what 
equations are used in the "trend" package for Mann-Kendall test and Theil-Sen estimator is available at [85].

QGIS ver. 3.10.9 and QGIS ver. 3.10.9 with GRASS ver. 7.8.3. were used in the study. Additionally, GIMP ver. 2.10.18 and Inkscape ver. 1.0.1 were used as graphic tools. In preparation of the Figure 3 the Inverse Distance Weighting (IDW) interpolation was used.
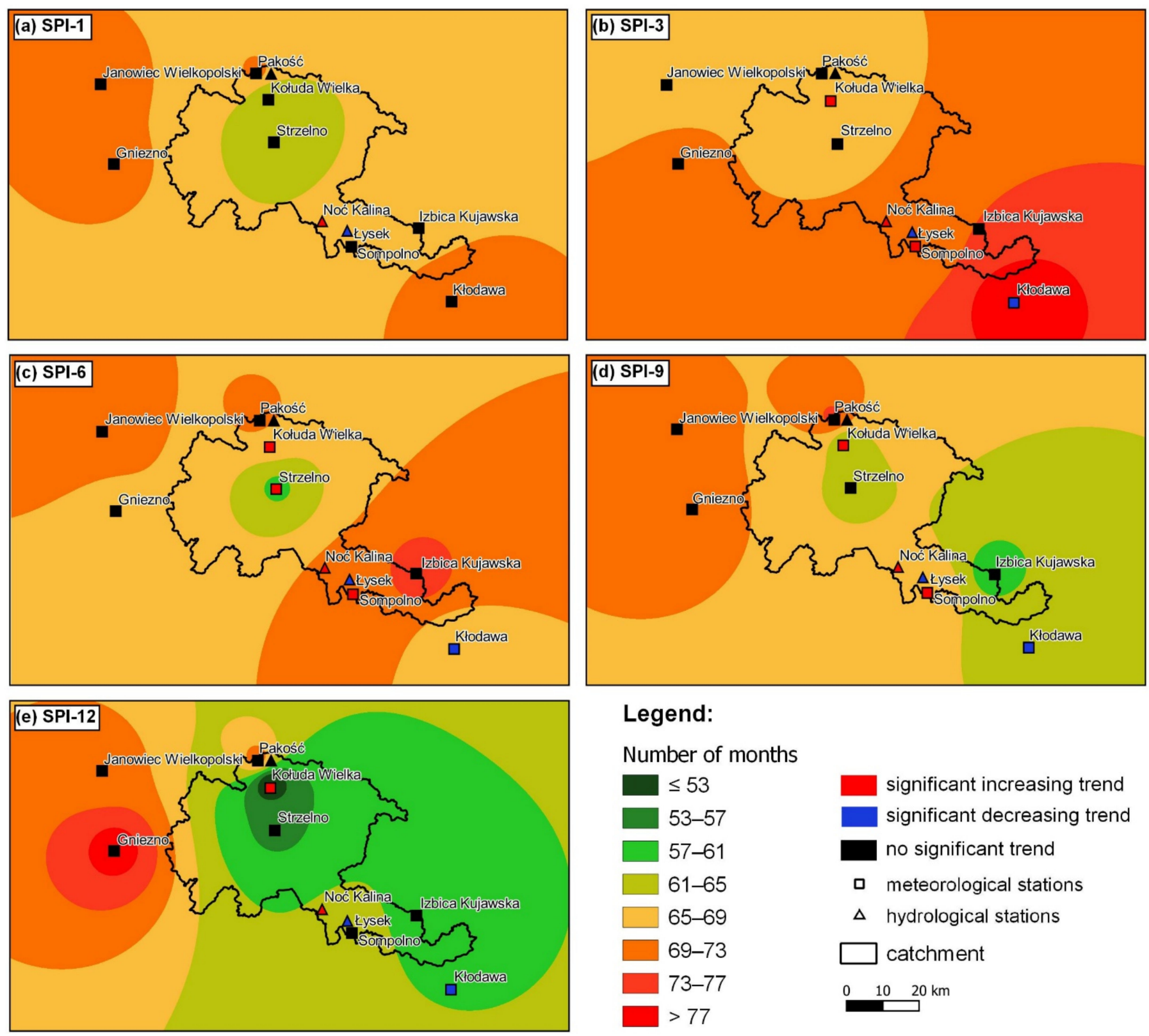

\section{Legend:}

\begin{tabular}{|l|l|}
$\begin{array}{l}\text { Number of months } \\
\leq 53\end{array}$ & significant increasing trend \\
$53-57$ & significant decreasing trend \\
$57-61$ & no significant trend \\
$61-65$ & $\square \quad$ meteorological stations \\
\hline $65-69$ & $\Delta \quad$ hydrological stations \\
$69-73$ & $\square$ catchment \\
$73-77$ & $0 \quad 10 \quad 20 \mathrm{~km}$ \\
\hline 77 & \\
\hline
\end{tabular}

Figure 3. Spatial distribution of the number of months with SPI $\leq-1.0$ in the period of 1981-2016. Source: (a-e) own elaboration made with [52], Table 4, Tables 6 and 7. Location of the stations based on [55,56] and Table 1. Meteorological station Izbica Kujawska is out of catchment area according to coordinates from Table 1. Location of the hydrological station Pakość is determined by cartographic issues. Maps elaborated in the coordinate system: WGS 84/UTM zone 34N. 
Table 4. Meteorological drought parameters (SPI) in different time scales in the period of 1981-2016.

\begin{tabular}{|c|c|c|c|c|c|}
\hline Parameters of Droughts & SPI-1 & SPI-3 & SPI-6 & SPI-9 & SPI-12 \\
\hline \multicolumn{6}{|c|}{ Izbica Kujawska } \\
\hline Number of months with SPI $\leq-1.0$ & 67 & 73 & 75 & 59 & 59 \\
\hline Number of months with SPI $\geq 1.0$ & 58 & 68 & 68 & 63 & 65 \\
\hline Minimum value of the index & -3.00 & -2.81 & -2.30 & -2.93 & -2.53 \\
\hline Maximum value of the index & 3.59 & 2.83 & 2.53 & 2.47 & 2.33 \\
\hline \multicolumn{6}{|c|}{ Sompolno } \\
\hline Number of months with SPI $\leq-1.0$ & 66 & 71 & 72 & 68 & 63 \\
\hline Number of months with SPI $\geq 1.0$ & 61 & 57 & 66 & 67 & 66 \\
\hline Minimum value of the index & -3.50 & -2.61 & -2.70 & -2.55 & -2.57 \\
\hline Maximum value of the index & 3.25 & 2.67 & 2.65 & 2.93 & 2.77 \\
\hline \multicolumn{6}{|c|}{ Strzelno } \\
\hline Number of months with SPI $\leq-1.0$ & 62 & 68 & 60 & 64 & 56 \\
\hline Number of months with SPI $\geq 1.0$ & 70 & 67 & 66 & 69 & 68 \\
\hline Minimum value of the index & -3.27 & -3.01 & -3.09 & -3.13 & -2.99 \\
\hline Maximum value of the index & 3.37 & 2.94 & 2.39 & 2.90 & 2.28 \\
\hline \multicolumn{6}{|c|}{ Kołuda Wielka } \\
\hline Number of months with SPI $\leq-1.0$ & 62 & 66 & 66 & 62 & 49 \\
\hline Number of months with SPI $\geq 1.0$ & 65 & 68 & 72 & 55 & 55 \\
\hline Minimum value of the index & -3.43 & -2.71 & -3.32 & -3.47 & -3.38 \\
\hline Maximum value of the index & 3.16 & 2.90 & 2.37 & 2.75 & 2.62 \\
\hline \multicolumn{6}{|c|}{ Pakość } \\
\hline Number of months with SPI $\leq-1.0$ & 70 & 69 & 71 & 74 & 71 \\
\hline Number of months with SPI $\geq 1.0$ & 66 & 70 & 69 & 69 & 72 \\
\hline Minimum value of the index & -3.54 & -2.83 & -2.80 & -2.67 & -2.69 \\
\hline Maximum value of the index & 2.80 & 2.64 & 2.35 & 2.90 & 2.12 \\
\hline \multicolumn{6}{|c|}{ Gniezno } \\
\hline Number of months with SPI $\leq-1.0$ & 70 & 70 & 68 & 72 & 79 \\
\hline Number of months with SPI $\geq 1.0$ & 64 & 65 & 67 & 67 & 61 \\
\hline Minimum value of the index & -3.43 & -2.95 & -2.73 & -2.73 & -2.66 \\
\hline Maximum value of the index & 2.50 & 2.37 & 2.45 & 2.70 & 2.10 \\
\hline \multicolumn{6}{|c|}{ Janowiec Wielkopolski } \\
\hline Number of months with SPI $\leq-1.0$ & 71 & 67 & 72 & 70 & 71 \\
\hline Number of months with SPI $\geq 1.0$ & 66 & 62 & 66 & 65 & 68 \\
\hline Minimum value of the index & -3.22 & -2.83 & -2.70 & -2.79 & -2.72 \\
\hline Maximum value of the index & 2.73 & 2.26 & 2.35 & 2.09 & 2.07 \\
\hline \multicolumn{6}{|c|}{ Kłodawa } \\
\hline Number of months with SPI $\leq-1.0$ & 73 & 81 & 66 & 65 & 61 \\
\hline Number of months with SPI $\geq 1.0$ & 52 & 72 & 74 & 68 & 69 \\
\hline Minimum value of the index & -3.09 & -2.92 & -2.60 & -2.72 & -2.46 \\
\hline Maximum value of the index & 3.26 & 2.26 & 2.35 & 2.58 & 2.35 \\
\hline
\end{tabular}

\subsection{Pearson's Correlation Analysis}

The Pearson correlation coefficient (r) was used to detect the relationship between meteorological droughts and hydrological droughts. With the use of this coefficient, it was possible to determine the linear relationship between the SPI and SRI variables in different accumulation periods. The value of the correlation coefficient is in a closed range $[-1,1]$. The greater its absolute value, the stronger the linear relationship between the variables. 0 -means there is no linear relation, $1-$ means a positive relation, and $-1-$ means a negative relation between the variables. 


\section{Results and Discussion}

\subsection{The Characteristics of Droughts in the Period of 1981-2016}

SPI values were calculated separately for all eight weather stations for the time scales of 1,3, 6, 9 and 12 months. Depending on the selected accumulation period, the range of SPI values was different for individual meteorological stations, as follows: SPI-1 from -3.54 to 3.59 , SPI-3 from -3.01 to 2.94 , SPI-6 from -3.32 to 2.65 , SPI-9 from -3.47 to 2.93 and SPI-12 from -3.38 to 2.77 (Table 4 ). The longer the indicator's accumulation period, the lower the drought intensity. The most intense meteorological droughts were recorded in the following periods: 1982-1985, 1989-1996, 2002-2006, 2008-2009. The number of months with drought occurrences varied, depending on the period of accumulation and distribution of individual meteorological stations. In the 1-month accumulation period, the number of months with drought occurrences (values $\leq-1.0$ ) ranged from 62 to 73 months i.e., from $14.3 \%$ to $16.9 \%$ of all the months in the analysed multi-year period of 1981-2016. On the other hand, wet months with SPI values $\geq 1.0$ lasted from 52 to 71 months i.e., from $12.0 \%$ to $16.4 \%$ of the analysed time period. In the case of SPI-1, the droughts lasted the longest in Kłodawa, and were the shortest in Kołuda and Strzelno. The highest number of months with drought occurrences (SPI $\leq-1.0$ ) in the 3-month accumulation period was recorded at the Kłodawa station (81 months), and the lowest in Kołuda Wielka (66 months). In the longer accumulation periods i.e., 6, 9 and 12 months, the number of months was similar and amounted to 60 to 75 months for SPI $-6,59$ to 74 months for SPI -9 and 59 to 79 months for SPI-12.

Greater differentiation was recorded in the cases of hydrological drought occurrences (SRI) at the station in Łysek, Noć Kalina and Pakość (Table 5). The SRI values in Łysek were characterized by the largest range i.e., from -5.22 to 2.00 . The most intense droughts were recorded from April to December of 2016, which was related to relatively minor discharges of the Noteć River during this period. At the Noć Kalina station, the SRI values recorded were from -3.16 to 2.49. The most intense hydrological droughts were recorded from May to September of 1990, depending on the period of accumulation. The SRI values in Pakość were characterized by a lower amplitude and ranged from -2.33 to 3.05. The number of months with SRI values below -1.0 ranged from 75 to 81 months, and in Noć Kalina-from 77 to 101 months.

Table 5. The Parameters of a hydrological drought (SRI) in different time scales in the period of 1981-2016.

\begin{tabular}{|c|c|c|c|c|c|}
\hline Parameters of Droughts & SRI-1 & SRI-3 & SRI-6 & SRI-9 & SRI-12 \\
\hline \multicolumn{6}{|c|}{ Pakość } \\
\hline Number of months with SPI $\leq-1.0$ & 75 & 77 & 77 & 81 & 79 \\
\hline Number of months with SPI $\geq 1.0$ & 68 & 67 & 73 & 75 & 76 \\
\hline Minimum value of the index & -2.33 & -2.20 & -2.20 & -1.93 & -1.71 \\
\hline Maximum value of the index & 2.34 & 2.30 & 2.83 & 3.05 & 2.71 \\
\hline \multicolumn{6}{|c|}{ Noć Kalina } \\
\hline Number of months with SPI $\leq-1.0$ & 77 & 83 & 86 & 101 & 99 \\
\hline Number of months with SPI $\geq 1.0$ & 72 & 76 & 67 & 58 & 59 \\
\hline Minimum value of the index & -3.16 & -3.10 & -2.79 & -2.23 & -2.25 \\
\hline Maximum value of the index & 2.49 & 2.31 & 1.97 & 2.05 & 1.92 \\
\hline \multicolumn{6}{|c|}{ Łysek } \\
\hline Number of months with SPI $\leq-1.0$ & 29 & 28 & 28 & 30 & 36 \\
\hline Number of months with SPI $\geq 1.0$ & 26 & 31 & 31 & 32 & 40 \\
\hline Minimum value of the index & -5.22 & -5.18 & -5.09 & -4.96 & -4.77 \\
\hline Maximum value of the index & 1.52 & 1.64 & 1.40 & 2.00 & 1.77 \\
\hline
\end{tabular}

The hydrological droughts (SRI $\geq-1.0$ ) at the station in Łysek were characterized by a short duration, from $6.5 \%$ to $8.3 \%$ of the analysed period, and high intensity. The number of wet months (SRI $\geq 1.0$ ) ranged from $6.0 \%$ to $9.3 \%$ of all the months of the analysed 
multiannual period. The largest number of months with SRI values $\leq-1.0$ was recorded at the Noć Kalina station i.e., from $17.9 \%$ to $23.4 \%$ of the analysed multi-year period, while the wet months constituted between $13.4 \%$ and $17.6 \%$ of this period. The hydrological station in Pakość closes the catchment area of the Upper Noteć River. The lower intensity of hydrological droughts at the Pakość station and their much shorter duration compared to the Noć Kalina and Łysek stations may have resulted from anthropogenic activities carried out in the area. These activities were mainly related to the lignite open pits, which ran south of the Łysek and Noć Kalina stations (Lubstów), as well as the operation of a new open pit mine located north of the Łysek station (Tomisławice).

The spatial distribution of the number of months with meteorological drought occurrences in the catchment area of the Upper Noteć is shown in Figure 3. The number of months with droughts in the accumulation period of 1 month does not present large spatial differentiation. Larger differences are noticeable in the period of 3- and 12-month accumulation. In the case of SPI-3, the months with droughts in the southern part of the catchment lasted the longest, while in the SPI-12 period they were the longest in the western part of the catchment.

Figure 4 shows the average values of SPI from 8 stations as well as the development of hydrological drought occurrences (SRI) recorded at the station in Pakość. The number of months with averaged meteorological droughts is between 13.4 and $15 \%$ of all the analysed months. As presented in Figure 4, the development of hydrological droughts is related to meteorological droughts.
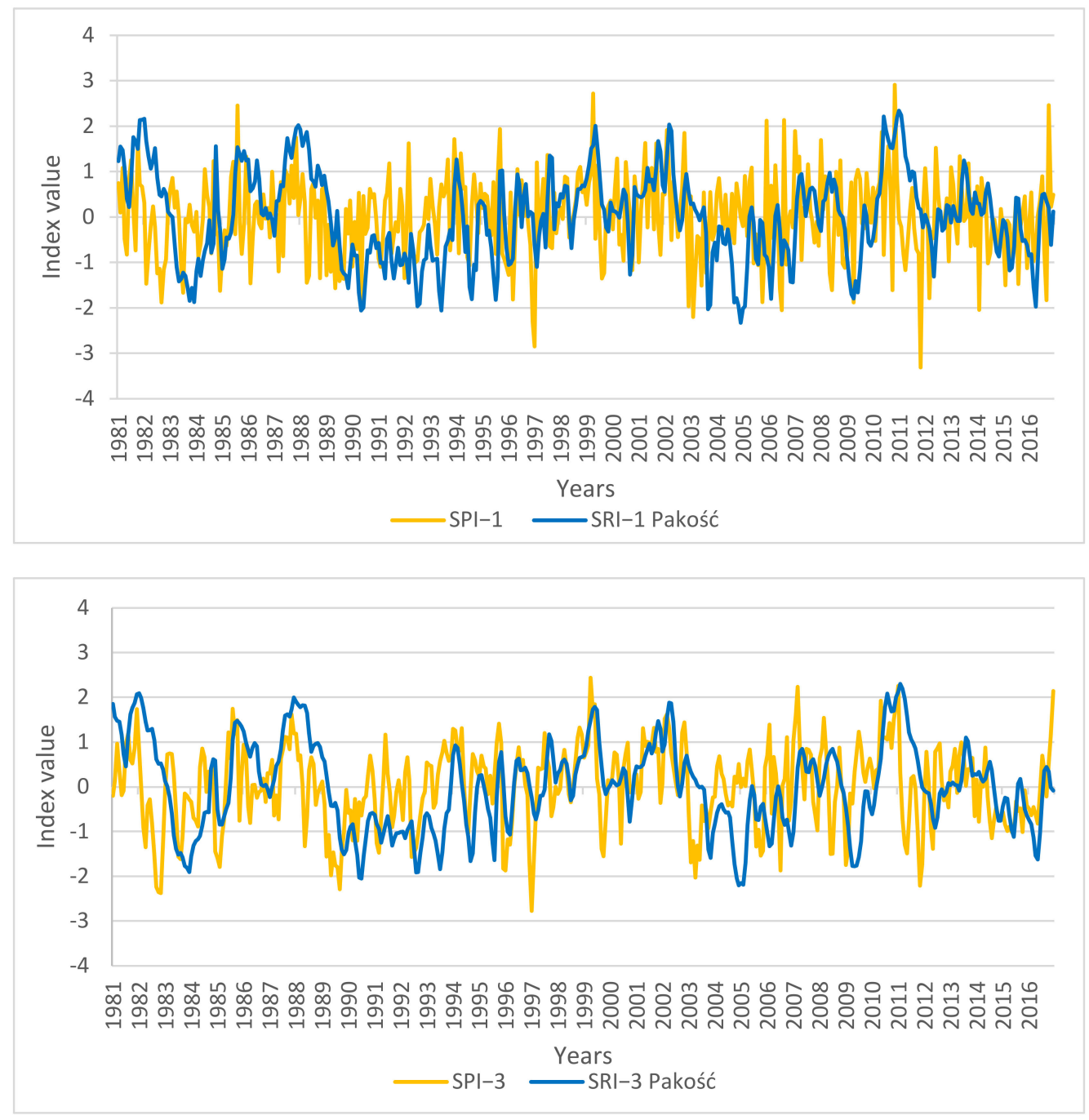

Figure 4. Cont. 

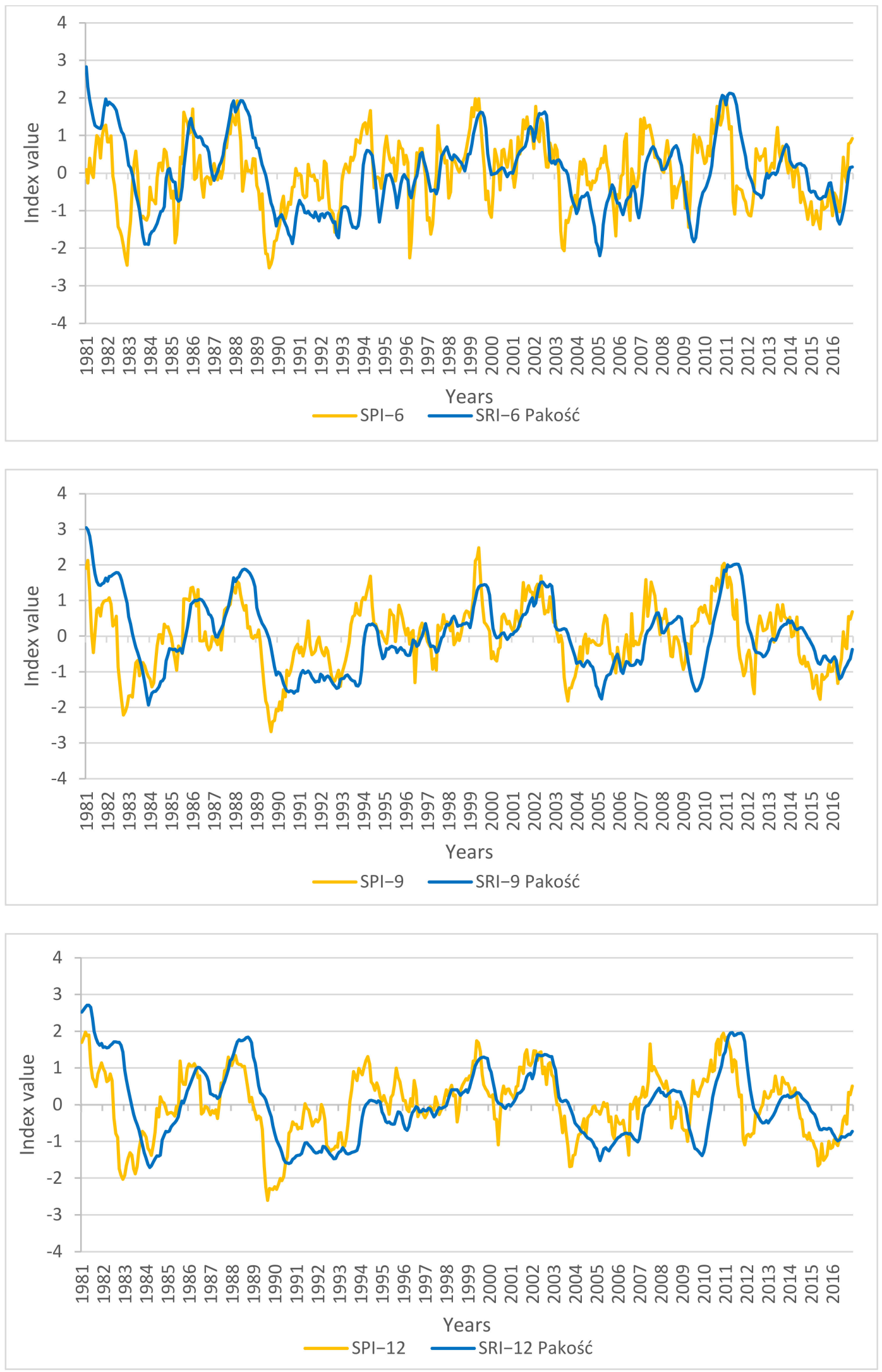

Figure 4. The development of meteorological and hydrological droughts in the period of 1981-2016 for different accumulation periods ( $n=1,3,6,9$ and 12), SPI—average values from 8 stations, SRI for Pakość. 


\subsection{Trends in Meteorological and Hydrological Drought Occurrences}

The results of the trend analysis for a series of SPI values (time scales of 1, 3, 6, 9 and 12 months) for individual meteorological stations are presented in Table 6. A statistically insignificant trend was noted at most meteorological stations. Out of eight meteorological stations, a statistically significant upward trend was recorded at only two stations, and a downward trend at one station (the drought intensified). The downward trend in the SPI value for the meteorological station in Kłodawa means that the meteorological drought increases in the period of accumulation of 3-12 months. The $\mathrm{Z}$ value obtained for the Kłodawa station was relatively high and ranged from -1.817 to -4.317 , and the TheilSen slope was between -0.0007 and -0.0018 . The test results for the Kłodawa station (Tables 6 and 7) show that the expected $Z$ value is negative for the indices, and the Theil-Sen slope is also always negative.

Table 6. Results of trend analysis SPI in different time scales in the period of 1981-2016 at meteorological stations.

\begin{tabular}{|c|c|c|c|c|c|c|}
\hline \multirow{2}{*}{ Stations } & \multirow{2}{*}{ Parameters } & \multicolumn{5}{|c|}{ SPI } \\
\hline & & SPI-1 & SPI -3 & SPI-6 & SPI -9 & SPI-12 \\
\hline \multirow{6}{*}{ Kłodawa } & $\mathrm{Z}$ & -1.817 & -2.429 & -3.179 & -3.755 & -4.318 \\
\hline & $S$ & $-5.45 \times 10^{3}$ & $-7.28 \times 10^{3}$ & $-9.53 \times 10^{3}$ & $-1.12 \times 10^{4}$ & $-1.29 \times 10^{4}$ \\
\hline & var_S & $8.99 \times 10^{6}$ & $8.99 \times 10^{6}$ & $8.99 \times 10^{6}$ & $8.99 \times 10^{6}$ & $8.99 \times 10^{6}$ \\
\hline & p-value & 0.0692 & 0.0151 & 0.0015 & 0.0002 & $1.58 \times 10^{-5}$ \\
\hline & Sen's slope & -0.0007 & -0.0010 & -0.0013 & -0.0016 & -0.0018 \\
\hline & & $\mathrm{N}$ & $\mathrm{D}$ & $\mathrm{D}$ & $\mathrm{D}$ & $\mathrm{D}$ \\
\hline \multirow{6}{*}{$\begin{array}{c}\text { Izbica } \\
\text { Kujawska }\end{array}$} & $\mathrm{Z}$ & -0.434 & 0.125 & 0.251 & 0.033 & -0.451 \\
\hline & $S$ & $-1.30 \times 10^{3}$ & $3.76 \times 10^{2}$ & $7.54 \times 10^{2}$ & $9.90 \times 10^{1}$ & $-1.35 \times 10^{3}$ \\
\hline & var_S & $8.99 \times 10^{6}$ & $8.99 \times 10^{6}$ & $8.99 \times 10^{6}$ & $8.99 \times 10^{6}$ & $8.99 \times 10^{6}$ \\
\hline & p-value & 0.6646 & 0.9005 & 0.8017 & 0.9739 & 0.6523 \\
\hline & Sen's slope & -0.0002 & $5.4386 \times 10^{-5}$ & 0.0001 & $1.50 \times 10^{-5}$ & -0.0002 \\
\hline & & $\mathrm{N}$ & $\mathrm{N}$ & $\mathrm{N}$ & $\mathrm{N}$ & $\mathrm{N}$ \\
\hline \multirow{6}{*}{ Sompolno } & $\mathrm{Z}$ & 1.253 & 2.180 & 2.413 & 2.090 & 1.648 \\
\hline & $S$ & $3.76 \times 10^{3}$ & $6.54 \times 10^{3}$ & $7.24 \times 10^{3}$ & $6.27 \times 10^{3}$ & $4.94 \times 10^{3}$ \\
\hline & var_S & $8.99 \times 10^{6}$ & $8.99 \times 10^{6}$ & $8.99 \times 10^{6}$ & $8.99 \times 10^{6}$ & $8.99 \times 10^{6}$ \\
\hline & p-value & 0.2102 & 0.0293 & 0.0158 & 0.0366 & 0.0994 \\
\hline & Sen's slope & 0.0005 & 0.0009 & 0.0010 & 0.0009 & 0.0007 \\
\hline & & $\mathrm{N}$ & I & I & I & $\mathrm{N}$ \\
\hline \multirow{6}{*}{ Strzelno } & Z & 1.223 & 1.728 & 2.034 & 1.341 & 0.908 \\
\hline & $S$ & $3.67 \times 10^{3}$ & $5.18 \times 10^{3}$ & $6.10 \times 10^{3}$ & $4.02 \times 10^{3}$ & $2.72 \times 10^{3}$ \\
\hline & var_S & $8.99 \times 10^{6}$ & $8.99 \times 10^{6}$ & $8.99 \times 10^{6}$ & $8.99 \times 10^{6}$ & $8.99 \times 10^{6}$ \\
\hline & $\mathrm{p}$-value & 0.2214 & 0.0840 & 0.0412 & 0.1801 & 0.3641 \\
\hline & Sen's slope & 0.0005 & 0.0007 & 0.0008 & 0.0006 & 0.0004 \\
\hline & & $\mathrm{N}$ & $\mathrm{N}$ & I & $\mathrm{N}$ & $\mathrm{N}$ \\
\hline \multirow{6}{*}{ Gniezno } & $Z$ & 0.453 & 1.272 & 1.916 & 1.790 & 1.506 \\
\hline & $S$ & $1.36 \times 10^{3}$ & $3.81 \times 10^{3}$ & $5.75 \times 10^{3}$ & $5.37 \times 10^{3}$ & $4.52 \times 10^{3}$ \\
\hline & var_S & $8.99 \times 10^{6}$ & $8.99 \times 10^{6}$ & $8.99 \times 10^{6}$ & $8.99 \times 10^{6}$ & $8.99 \times 10^{6}$ \\
\hline & $\mathrm{p}$-value & 0.6503 & 0.2035 & 0.0553 & 0.0734 & 0.1322 \\
\hline & Sen's slope & 0.0002 & 0.0005 & 0.0008 & 0.0007 & 0.0006 \\
\hline & & $\mathrm{N}$ & $\mathrm{N}$ & $\mathrm{N}$ & $\mathrm{N}$ & $\mathrm{N}$ \\
\hline \multirow{6}{*}{ Janowiec Wlkp. } & $\mathrm{Z}$ & -0.109 & -0.100 & -0.048 & -0.683 & -0.931 \\
\hline & $\mathrm{S}$ & $-3.27 \times 10^{2}$ & $-3.01 \times 10^{2}$ & $-1.45 \times 10^{2}$ & $-2.05 \times 10^{3}$ & $-2.79 \times 10^{3}$ \\
\hline & var_S & $8.99 \times 10^{6}$ & $8.99 \times 10^{6}$ & $8.99 \times 10^{6}$ & $8.99 \times 10^{6}$ & $8.99 \times 10^{6}$ \\
\hline & $\mathrm{p}$-value & 0.9134 & 0.9203 & 0.9617 & 0.4946 & 0.3517 \\
\hline & Sen's slope & $-4.40 \times 10^{-5}$ & $-3.78 \times 10^{-5}$ & $-1.81 \times 10^{-5}$ & -0.0003 & -0.0004 \\
\hline & & $\mathrm{N}$ & $\mathrm{N}$ & $\mathrm{N}$ & $\mathrm{N}$ & $\mathrm{N}$ \\
\hline
\end{tabular}


Table 6. Cont

\begin{tabular}{|c|c|c|c|c|c|c|}
\hline \multirow{2}{*}{ Stations } & \multirow{2}{*}{ Parameters } & \multicolumn{5}{|c|}{ SPI } \\
\hline & & SPI-1 & SPI-3 & SPI-6 & SPI-9 & SPI-12 \\
\hline \multirow{6}{*}{ Kołuda Wielka } & $\mathrm{Z}$ & 1.700 & 3.251 & 4.178 & 5.084 & 4.336 \\
\hline & $\mathrm{S}$ & $5.10 \times 10^{3}$ & $9.75 \times 10^{3}$ & $1.25 \times 10^{4}$ & $1.52 \times 10^{4}$ & $1.30 \times 10^{4}$ \\
\hline & var_S & $8.99 \times 10^{6}$ & $8.99 \times 10^{6}$ & $8.99 \times 10^{6}$ & $8.99 \times 10^{6}$ & $8.99 \times 10^{6}$ \\
\hline & p-value & 0.08918 & 0.0012 & $2.95 \times 10^{-5}$ & $3.69 \times 10^{-7}$ & $1.45 \times 10^{-5}$ \\
\hline & Sen's slope & 0.0007 & 0.0013 & 0.0016 & 0.0019 & 0.0016 \\
\hline & & $\mathrm{N}$ & I & I & I & I \\
\hline \multirow{6}{*}{ Pakość } & $\mathrm{Z}$ & 0.175 & 0.834 & 1.207 & 0.844 & 0.284 \\
\hline & $S$ & $5.27 \times 10^{2}$ & $2.50 \times 10^{3}$ & $3.62 \times 10^{3}$ & $2.53 \times 10^{3}$ & $8.51 \times 10^{2}$ \\
\hline & var_S & $8.99 \times 10^{6}$ & $8.99 \times 10^{6}$ & $8.99 \times 10^{6}$ & $8.99 \times 10^{6}$ & $8.99 \times 10^{6}$ \\
\hline & p-value & 0.8607 & 0.4044 & 0.2274 & 0.3986 & 0.7768 \\
\hline & Sen's slope & $7.48 \times 10^{-5}$ & 0.0003 & 0.0005 & 0.0003 & 0.0001 \\
\hline & & $\mathrm{N}$ & $\mathrm{N}$ & $\mathrm{N}$ & $\mathrm{N}$ & $\mathrm{N}$ \\
\hline
\end{tabular}

Description: N—no significant trend, D—significant decreasing trend, I—significant increasing trend.

Table 7. Results of trend analysis SRI in different time scales in the period of 1981-2016 at hydrological stations.

\begin{tabular}{|c|c|c|c|c|c|c|}
\hline \multirow{2}{*}{ Stations } & \multirow{2}{*}{ Parameters } & \multicolumn{5}{|c|}{ SRI } \\
\hline & & SRI-1 & SRI-3 & SRI-6 & SRI-9 & SRI-12 \\
\hline \multirow{6}{*}{ Łysek } & $\mathrm{Z}$ & -5.342 & -5.412 & 5.692 & -5.974 & -6.2735 \\
\hline & $\mathrm{S}$ & $-1.60 \times 10^{4}$ & $-1.62 \times 10^{4}$ & $-1.71 \times 10^{4}$ & $-1.79 \times 10^{4}$ & $-1.88 \times 10^{4}$ \\
\hline & var_S & $8.99 \times 10^{6}$ & $8.99 \times 10^{6}$ & $8.99 \times 10^{6}$ & $8.99 \times 10^{6}$ & $8.99 \times 10^{6}$ \\
\hline & $\mathrm{p}$-value & $9.19 \times 10^{-8}$ & $5.97 \times 10^{-8}$ & $1.25 \times 10^{-8}$ & $2.32 \times 10^{-9}$ & $3.53 \times 10^{-10}$ \\
\hline & Sen's slope & -0.0013 & -0.0014 & -0.0015 & -0.0017 & -0.0019 \\
\hline & & $\mathrm{D}$ & $\mathrm{D}$ & $\mathrm{D}$ & $\mathrm{D}$ & $\mathrm{D}$ \\
\hline \multirow{6}{*}{ Noć Kalina } & $\mathrm{Z}$ & 4.076 & 3.798 & 3.032 & 2.444 & 2.214 \\
\hline & S & $1.22 \times 10^{4}$ & $1.14 \times 10^{4}$ & $9.09 \times 10^{3}$ & $7.33 \times 10^{3}$ & $6.64 \times 10^{3}$ \\
\hline & var_S & $8.99 \times 10^{6}$ & $8.99 \times 10^{6}$ & $8.99 \times 10^{6}$ & $8.99 \times 10^{6}$ & $8.99 \times 10^{6}$ \\
\hline & p-value & $4.58 \times 10^{-5}$ & 0.00014 & 0.0024 & 0.0145 & 0.0268 \\
\hline & Sen's slope & 0.0017 & 0.0016 & 0.0013 & 0.0010 & 0.0008 \\
\hline & & I & I & I & I & I \\
\hline \multirow{6}{*}{ Pakość } & $\mathrm{Z}$ & -0.784 & -1.032 & -1.134 & -1.428 & -1.488 \\
\hline & $S$ & $-2.35 \times 10^{3}$ & $-3.10 \times 10^{3}$ & $-3.40 \times 10^{3}$ & $-4.28 \times 10^{3}$ & $-4.46 \times 10^{3}$ \\
\hline & var_S & $8.99 \times 10^{6}$ & $8.99 \times 10^{6}$ & $8.99 \times 10^{6}$ & $8.99 \times 10^{6}$ & $8.99 \times 10^{6}$ \\
\hline & p-value & 0.433 & 0.3019 & 0.2566 & 0.1533 & 0.1368 \\
\hline & Sen's slope & -0.0003 & -0.0004 & -0.0005 & -0.0006 & -0.0007 \\
\hline & & $\mathrm{N}$ & $\mathrm{N}$ & $\mathrm{N}$ & $\mathrm{N}$ & $\mathrm{N}$ \\
\hline
\end{tabular}

Description: N—no significant trend, D—significant decreasing trend, I-significant increasing trend.

The upward trend in the SPI value at the stations in Sompolno and Kołuda Wielka indicates that the phenomenon of meteorological drought is decreasing. The highest $Z$ values, between 3.25 and 5.08, were obtained during the 3-, 6-, 9- and 12-month accumulation periods, while the Theil-Sen slope values were between 0.009 and 0.0019 .

In the case of hydrological droughts, a statistically significant downward trend was recorded at the Łysek station in all analysed periods of accumulation. This means a noticeable increase in drought occurrences in the analysed multi-year period of 1981-2016. $Z$ values were negative and ranged from -5.34 to -6.27 , while Theil-Sen values were between -0.0013 to -0.0019 . An upward trend was recorded at the Noć Kalina station. $Z$ values ranged from 2.21 to 4.07 , while the Theil-Sen slope ranged from 0.0008 to 0.0017 . In the case of Pakość station, the trend was statistically insignificant. The $\mathrm{Z}$ value calculated in the 12-month accumulation period in Pakość approaches the region of a trend acceptance, which might indicate that the trend in Pakość in the longer accumulation period is determined by the occurrence of hydrological droughts at the Łysek station. 
Spatial distributions of trends (significant and insignificant) for a series of SPI and SRI values for the 1, 3-, 6-, 9- and 12-month time scales are shown in Figure 3.

\subsection{Correlations between SPI and SRI Values}

In order to establish the relationship between meteorological droughts occurring in the catchment area of the Upper Noteć and hydrological droughts, an analysis of the correlation between the SPI and SRI indices was carried out using the Pearson correlation analysis. The results showed that the strongest correlation between SPI and SRI in the analysed period of 1981-2016 was obtained at the 12-month time scale $(r=0.51)$ (Figure 5). In the case of individual years, the highest correlation indicators between hydrological and meteorological droughts varied depending on the length of the accumulation period. The strength of the relationship between SPI and SRI in the catchment area of the Upper Notec River was higher for long accumulation periods (6 and 9 months), and lower for the short ones ( 1 and 3 months). The highest correlation values for the 1-month accumulation period were recorded in $1998(\mathrm{r}=0.76)$, while for the 3-month accumulation period the highest values were recorded in $1982(\mathrm{r}=0.83)$ and $1996(\mathrm{r}=0.81)$. For the 6-month accumulation period, the maximum correlation index was recorded in $1987(\mathrm{r}=0.94)$ and in 1982 $(r=0.91)$. High values were obtained in 1987 for the 9-month accumulation period $(\mathrm{r}=0.94)$ and the 12-month accumulation period $(\mathrm{r}=0.90)$.

\subsection{Discussion}

Understanding the changes in the intensity of droughts in the past and being able to predict expected changes over different time scales is incredibly important, as precipitationdriven hydrological processes (e.g., evapotranspiration and surface and groundwater discharge) affect all water reserves [86]. In this study, we found that in the analysed period of 1981-2016, there was a relationship between the occurrence of meteorological and hydrological droughts. The strength of this relationship varied. The analysed multi-year period of 1981-2016 showed a high variability, from dry years (SPI $\leq-1.0$ ) to wet years (SPI $\geq 1.0$ ), which can be concluded from the SPI values in various time scales. The driest years included 1982, 1989, 1992, 2003 and 2015. In these years, meteorological droughts covering not only the region of Poland, but parts of Europe, were recorded. Meteorological droughts which have occurred in Europe since the beginning of the 21st century, and were accompanied by heat waves in 2003, 2006, 2010, 2015, are great examples of such phenomena [87-91].

In the studied area, an increase in the intensity of meteorological droughts (downward trend) was observed at only one out of eight meteorological stations. A statistically significant, clear upward trend in SPI drought was identified at two stations. More distinct trends, but opposite in direction, were observed in the case of hydrological droughts recorded at the stations in Łysek and Noć Kalina. The obtained statistics for the Pakość station, calculated in the 12-month accumulation period, point to the rejection of the null hypothesis on the lack of a statistically significant trend. The same direction of changes in the trend was recorded at the Łysek and Pakość stations. This means an increase in the intensity of hydrological droughts. In the longer accumulation period, the occurrence of hydrological droughts at the Eysek station determines the hydrological droughts at the Pakość station.

The strength of the relationship between meteorological droughts and hydrological droughts shows significant variation. This variation is not only the result of the size of the annual sums of precipitation, but also if an increase in air temperature in the analysed area (Figure 2), which leads to an increase in evapotranspiration [92]. Anthropogenic activities related to the operation of a lignite open pit have a significant impact on the analysed area. Some of the water from the mine drainage was directed to the Notec River above the Noć Kalina station. The amount of water varied in individual years and depended on the location of the exploitation operations. According to Wachowiak [93], in the period of 1995-2009 the Upper Noteć was flooded with some of the mine water from 
the drainage of the Lubstów open pit. Since 2009, there have been cases of mine water discharge from the Tomisławice open pit via the Pichna River. The correlations between meteorological and hydrological droughts were variable, in some years the strength of the relationship was high (positive correlation), while in other years the relationship was low (negative correlation).
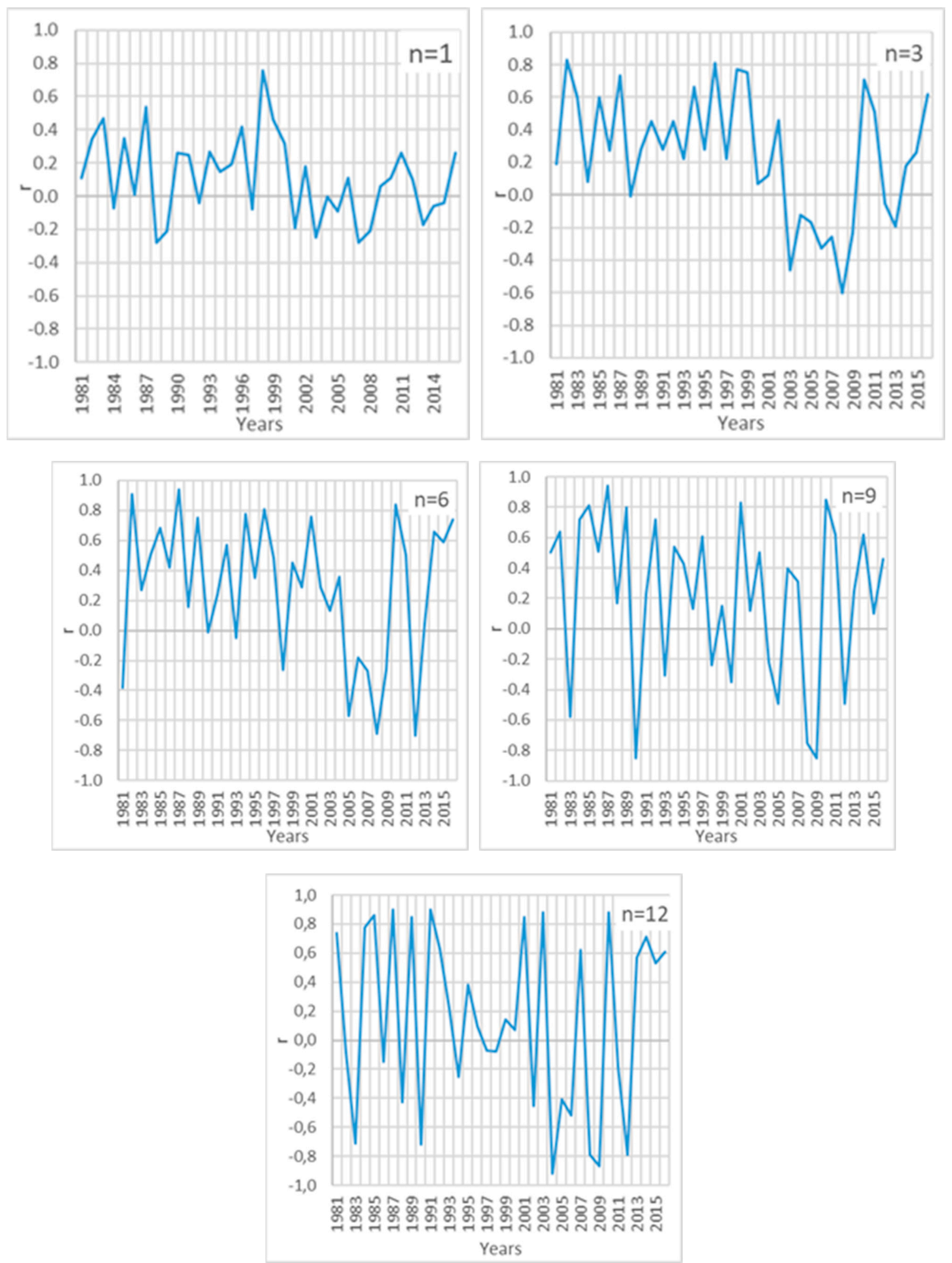

Figure 5. Correlation coefficient $\mathrm{r}$ between average SPI and SRI in Pakość for different periods of accumulation in the period of 1981-2016 (n-number of accumulated months). 
The Pearson correlation analysis shows that there is a relationship between meteorological and hydrological droughts in the study area. However, it should be emphasized that these results should not be directly interpreted. In the correlation analysis, a nonlinear relationship can be inadequately described or undetected [94]. Non-linear models (polynomial, exponential and logarithmic) for the relationship between meteorological and hydrological droughts were analysed in the research conducted by Salimi et al. [95].

The research on the correlation between droughts conducted by Tokarczyk and Szalińska [44] for catchments with large areas showed that the largest correlations between SPI and SRI occurred for longer periods of accumulation. Similar relationships between meteorological and hydrological droughts were obtained for other catchments in Poland [43]. In the case of the catchment area of the Upper Noteć River, the relationships between meteorological and hydrological conditions are not natural. The flow regime depends on the amount of water discharged in particular periods, and on the retention capacity of lakes, which is particularly noticeable at the Pakość station. The amount of water accumulated in the Pakość reservoir, through which the Noteć flows, is regulated by a water accumulating weir.

\section{Conclusions}

The study analysed the trends in meteorological and hydrological drought occurrences in the long-term period of 1981-2016, for the catchment area of the Upper Noteć River. The identification of a meteorological drought was carried out with the use of an SPI, based on monthly precipitation totals from eight meteorological stations. Hydrological drought was determined by means of an SRI for the monthly discharges of the Noteć, which were obtained from three hydrological stations. Non-parametric Mann-Kendall tests and the Sen slope were used to determine trends. The following conclusions might be drawn:

- $\quad$ Statistically significant trends, at the significance level of 0.05 , were identified at three out of eight meteorological stations, based on the Mann-Kendall test and the Sen slope.

- $\quad$ An increase in meteorological drought occurrences was recorded at the Kłodawa station (downward trend), while a decrease in droughts was recorded at the Sompolno and Kołuda Wielka stations.

- Hydrological droughts showed an upward trend at the Łysek station, while a decrease in the trend was recorded at the Noć Kalina station, and both were statistically significant. No changes in the trend were found at the Pakość station.

- The analysis of the correlation between meteorological and hydrological droughts in individual years showed a strong relationship in dry years e.g., 1982 and 1989. The maximum correlation index was 0.94 and was identified over longer accumulation periods i.e., 6 and 9 months.

- The anthropogenic effects related to the operation of an open cast lignite mine may have had an impact on the relationship between droughts.

The example of the catchment area of the Upper Noteć River indicates that the management of water resources requires the use of at least several indicators that will allow an assessment of the actual state of water reserves. Using the SPI to detect meteorological droughts can be used as a drought warning system [96]. In some cases, the value of the SRI depends on the way water is managed within the catchment area. The size of the runoff may be disturbed by anthropogenic factors. Effective water resource management strategies require constant monitoring of water reserves, which should be consulted among various stakeholder groups related in particular to industry, and agriculture.

Author Contributions: Conceptualization, K.K.-W., A.P. and D.K.; methodology, K.K.-W. and A.P.; software, K.K.-W. and A.P.; validation, K.K.-W. and A.P.; formal analysis, K.K.-W., A.P. and D.K.; resources, K.K.-W. and A.P.; data curation, K.K.-W. and A.P.; writing-original draft preparation, K.K.-W.; writing-review and editing, K.K.-W., A.P. and D.K.; visualization, A.P.; supervision, 
K.K.-W., A.P. and D.K.; project administration, K.K.-W. All authors have read and agreed to the published version of the manuscript.

Funding: This research received no external funding.

Institutional Review Board Statement: Not applicable.

Informed Consent Statement: Not applicable.

Data Availability Statement: The datasets used and/or analyzed during the current study are available from the corresponding author on reasonable request.

Conflicts of Interest: The authors declare no conflict of interest.

\section{References}

1. Nalbantis, I.; Tsakiris, G. Assessment of Hydrological Drought Revisited. Water Resour. Manag. 2009, 23, 881-897. [CrossRef]

2. Chen, S.-T.; Kuo, C.-C.; Yu, P.-S. Historical trends and variability of meteorological droughts in Taiwan. Hydrol. Sci. J. 2009, 54, 430-441. [CrossRef]

3. Roodari, A.; Hrachowitz, M.; Hassanpour, F.; Yaghoobzadeh, M. Signatures of human intervention-Or not? Downstream intensification of hydrological drought along a large Central Asian river: The individual roles of climate variability and land use change. Hydrol. Earth Syst. Sci. 2021, 25, 1943-1967. [CrossRef]

4. Bae, H.; Ji, H.; Lim, Y.-J.; Ryu, Y.; Kim, M.-H.; Kim, B.-J. Characteristics of drought propagation in South Korea: Relationship between meteorological, agricultural, and hydrological droughts. Nat. Hazards 2019, 99, 1-16. [CrossRef]

5. Faridatul, M.; Ahmed, B. Assessing Agricultural Vulnerability to Drought in a Heterogeneous Environment: A Remote SensingBased Approach. Remote Sens. 2020, 12, 3363. [CrossRef]

6. Dai, A. Drought under global warming: A review. Wiley Interdiscip. Rev. Clim. Chang. 2011, 2, 45-65. [CrossRef]

7. Tian, L.; Yuan, S.; Quiring, S. Evaluation of six indices for monitoring agricultural drought in the south-central United States. Agric. For. Meteorol. 2018, 249, 107-119. [CrossRef]

8. Wilhite, D.A.; Glantz, M.H. Understanding: The Drought Phenomenon: The Role of Definitions. Water Int. 1985, 10, 111-120. [CrossRef]

9. Bąk, B.; Kubiak-Wójcicka, K.K. Assessment of meteorological and hydrological drought in Torun (central Poland town) in 1971-2010 based on standardized indicators. In Proceedings of the Water Resources and Wetlands Conference, Tulcea, Romania, 8-10 September 2016; Gastescu, P., Bretcan, P., Eds.; pp. 164-170. Available online: http://www.limnology.ro/wrw2016/ proceedings/22_Bak_Kubiak.pdf (accessed on 15 July 2021).

10. Hasan, H.H.; Razali, S.F.M.; Muhammad, N.S.; Hamzah, F.M. Assessment of probability distributions and analysis of the minimum storage draft rate in the equatorial region. Nat. Hazards Earth Syst. Sci. 2021, 21, 1-19. [CrossRef]

11. Zhao, F.; Wu, Y.; Sivakumar, B.; Long, A.; Qiu, L.; Chen, J.; Wang, L.; Liu, S.; Hu, H. Climatic and hydrologic controls on net primary production in a semiarid loess watershed. J. Hydrol. 2018, 568, 803-815. [CrossRef]

12. Wu, J.; Chen, X.; Love, C.A.; Yao, H.; Chen, X.; AghaKouchak, A. Determination of water required to recover from hydrological drought: Perspective from drought propagation and non-standardized indices. J. Hydrol. 2020, 590, 125227. [CrossRef]

13. Jehanzaib, M.; Sattar, M.N.; Lee, J.-H.; Kim, T.-W. Investigating effect of climate change on drought propagation from meteorological to hydrological drought using multi-model ensemble projections. Stoch. Environ. Res. Risk Assess. 2019, 34, 7-21. [CrossRef]

14. Gleick, P. Water, Drought, Climate Change, and Conflict in Syria. Weather. Clim. Soc. 2014, 6, 331-340. [CrossRef]

15. Craft, K.E.; Mahmood, R.; King, S.A.; Goodrich, G.; Yan, J. Twentieth century droughts and agriculture: Examples from impacts on soybean production in Kentucky, USA. Ambio 2015, 44, 557-568. [CrossRef]

16. Holman, I.; Hess, T.; Rey, D.; Knox, J. A Multi-Level Framework for Adaptation to Drought Within Temperate Agriculture. Front. Environ. Sci. 2021, 8. [CrossRef]

17. Spinoni, J.; Barbosa, P.; Bucchignani, E.; Cassano, J.; Cavazos, T.; Christensen, J.H.; Christensen, O.B.; Coppola, E.; Evans, J.; Geyer, B.; et al. Future Global Meteorological Drought Hot Spots: A Study Based on CORDEX Data. J. Clim. 2020, 33, 3635-3661. [CrossRef]

18. IPCC. Changes in Climate Extremes and Their Impacts on the Natural Physical Environment. In Managing the Risks of Extreme Events and Disasters to Advance Climate Change Adaptation: Special Report of the Intergovernmental Panel on Climate Change; Field, C.B., Barros, V., Stocker, T.F., Qin, D., Dokken, D.J., Ebi, K.L., Mastrandrea, M.D., Mach, K.J., Plattner, G.-K., Allen, S.K., et al., Eds.; Cambridge University Press: Cambridge, UK, 2012.

19. Vicente-Serrano, S.M.; Dominguez-Castro, F.; McVicar, T.R.; Tomas-Burguera, M.; Peña-Gallardo, M.; Noguera, I.; López-Moreno, J.I.; Peña, D.; El Kenawy, A. Global characterization of hydrological and meteorological droughts under future climate change: The importance of timescales, vegetation- $\mathrm{CO}_{2}$ feedbacks and changes to distribution functions. Int. J. Clim. 2019, 40, $2557-2567$. [CrossRef]

20. Chiang, F.; Mazdiyasni, O.; AghaKouchak, A. Evidence of anthropogenic impacts on global drought frequency, duration, and intensity. Nat. Commun. 2021, 12, 2754. [CrossRef] 
21. Jehanzaib, M.; Kim, T.-W. Exploring the influence of climate change-induced drought propagation on wetlands. Ecol. Eng. 2020, 149, 105799. [CrossRef]

22. Gao, L.; Zhang, Y. Spatio-temporal variation of hydrological drought under climate change during the period 1960-2013 in the Hexi Corridor, China. Arid Land 2016, 82, 157-171. [CrossRef]

23. Ndehedehe, C.E.; Agutu, N.O.; Ferreira, V.G.; Getirana, A. Evolutionary drought patterns over the Sahel and their teleconnections with low frequency climate oscillations. Atmos. Res. 2019, 233, 104700. [CrossRef]

24. Bazrafshan, O.; Zamani, H.; Shekari, M. A copula-based index for drought analysis in arid and semi-arid regions in Iran. Nat. Resour. Model. 2020, 33, e12237. [CrossRef]

25. Dikici, M. Drought analysis with different indices for the Asi Basin (Turkey). Sci. Rep. 2020, 10, 1-12. [CrossRef]

26. Mahdavi, P.; Kharazi, H.G.; Eslami, H.; Zohrabi, N.; Razaz, M. Drought occurrence under future climate change scenarios in the Zard River basin, Iran. Water Supply 2020, 21, 899-917. [CrossRef]

27. Buras, A.; Rammig, A.; Zang, C.S. Quantifying impacts of the 2018 drought on European ecosystems in comparison to 2003. Biogeosciences 2020, 17, 1655-1672. [CrossRef]

28. Kubiak-Wójcicka, K.; Nagy, P.; Zeleňáková, M.; Hlavatá, H.; Abd-Elhamid, H. Identification of Extreme Weather Events Using Meteorological and Hydrological Indicators in the Laborec River Catchment, Slovakia. Water 2021, 13, 1413. [CrossRef]

29. Emadodin, I.; Corral, D.; Reinsch, T.; Kluß, C.; Taube, F. Climate Change Effects on Temperate Grassland and Its Implication for Forage Production: A Case Study from Northern Germany. Agriculture 2021, 11, 232. [CrossRef]

30. Koffi, B.; Kouadio, Z.A.; Kouassi, K.H.; Yao, A.B.; Sanchez, M. Impact of Meteorological Drought on Streamflows in the Lobo River Catchment at Nibéhibé, Côte d'Ivoire. J. Water Resour. Prot. 2020, 12, 495-511. [CrossRef]

31. Awange, J.L.; Mpelasoka, F.; Goncalves, R. When every drop counts: Analysis of Droughts in Brazil for the 1901-2013 period. Sci. Total Environ. 2016, 566-567, 1472-1488. [CrossRef] [PubMed]

32. Hari, V.; Rakovec, O.; Markonis, Y.; Hanel, M.; Kumar, R. Increased future occurrences of the exceptional 2018-2019 Central European drought under global warming. Sci. Rep. 2020, 10, 1-10. [CrossRef]

33. Kubiak-Wójcicka, K. Assessment of water resources in Poland. In Quality in Water Resources in Poland; Zeleňáková, M., KubiakWójcicka, K., Negm, A.M., Eds.; Springer International Publishing: Cham, Switzerland, 2021; pp. 15-34. [CrossRef]

34. Somorowska, U. Changes in Drought Conditions in Poland over the Past 60 Years Evaluated by the Standardized PrecipitationEvapotranspiration Index. Acta Geophys. 2016, 64, 2530-2549. [CrossRef]

35. Szwed, M. Variability of precipitation in Poland under climate change. Theor. Appl. Clim. 2018, 135, 1003-1015. [CrossRef]

36. Kubiak-Wójcicka, K. Dynamics of meteorological and hydrological droughts in the agricultural catchments. Res. Rural Dev. 2019, 1,111-117. [CrossRef]

37. Tomczyk, A.M.; Szyga-Pluta, K. Variability of thermal and precipitation conditions in the growing season in Poland in the years 1966-2015. Theor. Appl. Clim. 2018, 135. [CrossRef]

38. Osuch, M.; Romanowicz, R.J.; Booij, M.J. The influence of parametric uncertainty on the relationships between HBV model parameters and climatic characteristics. Hydrol. Sci. J. 2015, 60, 1299-1316. [CrossRef]

39. Łabędzki, L.; Bak, B. Indicator-based monitoring and forecasting water deficit and surplus in agriculture in Poland. Ann. Wars. Univ. Life Sci. SGGW Land Reclam. 2015, 47, 355-369. [CrossRef]

40. Kuśmierek-Tomaszewska, R.; Żarski, J.; Dudek, S. Assessment of Irrigation Needs in Sugar Beet (Beta vulgaris L.) in Temperate Climate of Kujawsko-Pomorskie Region (Poland). Agronomy 2019, 9, 814. [CrossRef]

41. Łabedzki, L. Estimation of local drought frequency in central Poland using the standardized precipitation index SPI. Irrig. Drain. 2007, 56, 67-77. [CrossRef]

42. Tokarczyk, T.; Szalińska, W. Combined analysis of precipitation and water deficit for drought hazard assessment. Hydrol. Sci. J. 2014, 59, 1675-1689. [CrossRef]

43. Kubiak-Wójcicka, K.; Bąk, B. Monitoring of meteorological and hydrological droughts in the Vistula basin (Poland). Environ. Monit. Assess. 2018, 190, 691. [CrossRef]

44. Tokarczyk, T.; Szalińska, W.; National Research Institute. Drought Hazard Assessment in the Process of Drought Risk Management. Acta Sci. Pol. Form. Circumiectus 2018, 3, 217-229. [CrossRef]

45. Łabędzki, L.; Bąk, B. Impact of meteorological drought on crop water deficit and crop yield reduction in Polish agriculture. J. Water Land Dev. 2017, 34, 181-190. [CrossRef]

46. Kubiak-Wójcicka, K.; Juśkiewicz, W. Relationships between meteorological and hydrological drought in a young-glacial zone (north-western Poland) based on Standardised Precipitation Index (SPI) and Standardized Runoff Index (SRI). Acta Montan. Slovaca 2020, 25, 517-531. [CrossRef]

47. Bąk, B.; Kubiak-Wójcicka, K. Impact of meteorological drought on hydrological drought in Torun (central Poland) in the period of 1971-2015. J. Water Land Dev. 2017, 32, 3-12. [CrossRef]

48. Radzka, E. The assessment of atmospheric drought during vegetation season (according to Standardized Precipitation Index SPI) in central-eastern Poland. J. Ecol. Eng. 2015, 16, 87-91. [CrossRef]

49. Grzywna, A.; Bochniak, A.; Ziernicka-Wojtaszek, A.; Krużel, J.; Jóźwiakowski, K.; Wałega, A.; Cupak, A.; Mazur, A.; Obroślak, R.; Serafin, A. The analysis of spatial variability of precipitation in Poland in the multiyears 1981-2010. J. Water Land Dev. 2020, 46, 105-111. [CrossRef]

50. Bąk, B. Warunki klimatyczne Wielkopolski i Kujaw. Woda-Środowisko-Obszary Wiejskie 2003, 3, 11-39. 
51. Natural Earth. Free Vector and Raster Map Data @ naturalearthdata.com. Available online: https:/ /www.naturalearthdata.com/ downloads/10m-cultural-vectors and https://www.naturalearthdata.com/downloads/10m-raster-data/10m-natural-earth-1 (accessed on 12 July 2021).

52. Wektorowe Warstwy Tematyczne aPGW. Available online: https://dane.gov.pl/pl/dataset/599//resource/672, wektorowewarstwy-tematyczne-apgw/table (accessed on 12 July 2021).

53. SRTM 1 Arc-Second Global. Available online: https://earthexplorer.usgs.gov/ (accessed on 3 June 2021). [CrossRef]

54. Baza Danych Obiektów Ogólnogeograficznych. Available online: https://mapy.geoportal.gov.pl/imap/Imgp_2.html?locale=pl\& gui=new\&sessionID=5160004 (accessed on 15 July 2021).

55. Hydro IMGW-PIB. Available online: https:/ / hydro.imgw.pl/\#map/19.5,51.5,7, true, true,0 (accessed on 15 July 2021 ).

56. QGIS Quick Map Services Plugin. OSM Standard. Plugin Was Used on 13-15 July 2021. Author of the Plugin: NextGIS. Base Map from: OpenStreetMap and OpenStreetMap Foundation. Detailed Information about Copyright and License of the OpenStreetMap. Available online: https:/ / www.openstreetmap.org/copyright (accessed on 15 July 2021).

57. Przybyłek, J. Aktualne problemy odwadniania złóż węla brunatnego w Wielkopolsce. Górnictwo Odkrywkowe 2018, 59, 5-14.

58. Kubiak-Wójcicka, K.; Machula, S. Influence of Climate Changes on the State of Water Resources in Poland and Their Usage. Geosciences 2020, 10, 312. [CrossRef]

59. Tomaszewski, E.; Kubiak-Wójcicka, K. Low-flows in Polish rivers. In Management of Water Resources in Poland; Zeleňáková, M., Kubiak-Wójcicka, K., Negm, A.M., Eds.; Springer International Publishing: Cham, Switzerland, 2021; pp. 205-228. [CrossRef]

60. McKee, T.B.; Doesken, N.J.; Kleist, J. The relationship of drought frequency and duration to time scales. In Proceedings of the 8th Conference of Applied Climatology, Anaheim, CA, USA, 17-22 January 1993; pp. 179-184.

61. World Meteorological Organization (WMO); Global Water Partnership (GWP). Handbook of Drought Indicators and Indices; Integrated Drought Management Tools and Guidelines Series 2; Svoboda, M., Fuchs, B.A., Eds.; Integrated Drought Management Programme (IDMP): Geneva, Switzerland, 2016; ISBN 978-92-63-11173-9.

62. Guttman, N.B. Accepting the Standardized Precipitation Index: A calculation algorithm. J. Am. Water Resour. Assoc. 1999, 35, 311-322. [CrossRef]

63. Lloyd-Hughes, B.; Saunders, M. A drought climatology for Europe. Int. J. Clim. 2002, 22, 1571-1592. [CrossRef]

64. Fang, W.; Huang, S.; Huang, Q.; Huang, G.; Wang, H.; Leng, G.; Wang, L. Identifying drought propagation by simultaneously considering linear and nonlinear dependence in the Wei River basin of the Loess Plateau, China. J. Hydrol. 2020, $591,125287$. [CrossRef]

65. Łabędzki, L. Actions and measures for mitigation drought and water scarcity in agriculture. J. Water Land Dev. 2016, 29, 3-10. [CrossRef]

66. Lorenzo-Lacruz, J.; Morán-Tejeda, E.; Vicente-Serrano, S.M.; López-Moreno, J.I. Streamflow droughts in the Iberian Peninsula between 1945 and 2005: Spatial and temporal patterns. Hydrol. Earth Syst. Sci. 2013, 17, 119-134. [CrossRef]

67. Sahoo, R.N.; Dipanwita, D.; Khanna, M.; Kumar, N.; Bandyopadhyay, S.K. Drought assessment in the Dhar and Mewat Districs of India using meteorological and remote-sensing derived indices. Nat. Hazards 2015, 77, 733-751. [CrossRef]

68. Shukla, S.; Wood, A. Use of a standardized runoff index for characterizing hydrologic drought. Geophys. Res. Lett. 2008, 35. [CrossRef]

69. Bayissa, Y.; Maskey, S.; Tadesse, T.; Van Andel, S.J.; Moges, S.; Van Griensven, A.; Solomatine, D. Comparison of the Performance of Six Drought Indices in Characterizing Historical Drought for the Upper Blue Nile Basin, Ethiopia. Geosciences $2018,8,81$. [CrossRef]

70. Vicente-Serrano, S.M.; Lopez-Moreno, I.; Beguería, S.; Lorenzo-Lacruz, J.; Azorin-Molina, C.; Morán-Tejeda, E. Accurate Computation of a Streamflow Drought Index. J. Hydrol. Eng. 2012, 17, 318-332. [CrossRef]

71. Mann, H.B. Nonparametric tests against trend. Econometrica 1945, 13, 245-259. [CrossRef]

72. Kendall, M.G. Rank Correlation Methods; Charles Grin: London, UK, 1975.

73. Silva, A.; Filho, M.; Menezes, R.; Stosic, T.; Stosic, B. Trends and Persistence of Dry-Wet Conditions in Northeast Brazil. Atmosphere 2020, 11, 1134. [CrossRef]

74. Bacanli, G. Trend analysis of precipitation and drought in the Aegean region, Turkey. Meteorol. Appl. 2017, 24, 239-249. [CrossRef]

75. Hu, M.; Dong, M.; Tian, X.; Wang, L.; Jiang, Y. Trends in Different Grades of Precipitation over the Yangtze River Basin from 1960 to 2017. Atmosphere 2021, 12, 413. [CrossRef]

76. Gocic, M.; Trajkovic, S. Analysis of changes in meteorological variables using Mann-Kendall and Sen's slope estimator statistical tests in Serbia. Glob. Planet. Chang. 2013, 100, 172-182. [CrossRef]

77. Tuan, N.H.; Canh, T.T. Analysis of Trends in Drought with the Non-Parametric Approach in Vietnam: A Case Study in Ninh Thuan Province. Am. J. Clim. Chang. 2021, 10, 51-84. [CrossRef]

78. Kuriqi, A.; Ali, R.; Quoc Bao, P.; Gambini, J.M.; Gupta, V.; Malik, A.; Nguyen Thi Thuy, L.; Joshi, Y.; Duong Tran, A.; Van Thai, N.; et al. Seasonality shift and streamflow flow variability trends in central India. Acta Geophys. 2020, 68, 1461-1475. [CrossRef]

79. Abeysingha, N.S.; Rajapaksha, U.R.L.N. SPI-Based Spatiotemporal Drought over Sri Lanka. Hindawi Adv. Meteorol. 2020. [CrossRef]

80. Sen, P.K. Estimates of the regression coefficient based on Kendall's tau. J. Am. Stat. Assoc. 1968, 63, 1379-1389. [CrossRef]

81. Achite, M.; Krakauer, N.; Wałęga, A.; Caloiero, T. Spatial and Temporal Analysis of Dry and Wet Spells in the Wadi Cheliff Basin, Algeria. Atmosphere 2021, 12, 798. [CrossRef] 
82. RStudio Team. RStudio: Integrated Development Environment for R; RStudio PBC: Boston, MA, USA, 2021.

83. Wickham, H.; Bryan, J. Readxl: Read Excel Files. R Package Version 1.3.1. 2019. Available online: https:/ /CRAN.R-project.org/ package $=$ readxl (accessed on 17 July 2021).

84. Pohlert, T. Trend: Non-Parametric Trend Tests and Change-Point Detection. R package Version 1.1.4. 2020. Available online: https:/ /CRAN.R-project.org/package=trend (accessed on 17 July 2021).

85. Reference Manual. Package "Trend". Non-Parametric Trend Tests and Change-Point Detection. Available online: https: / / cran.r-project.org/web/packages/trend/trend.pdf (accessed on 8 August 2021).

86. Portela, M.M.; Espinosa, L.A.; Zelenakova, M. Long-Term Rainfall Trends and Their Variability in Mainland Portugal in the Last 106 Years. Climate 2020, 8, 146. [CrossRef]

87. Ionita, M.; Tallaksen, L.M.; Kingston, D.G.; Stagge, J.H.; Laaha, G.; Van Lanen, H.A.J.; Chelcea, S.M.; Haslinger, K. The European 2015 drought from a climatological perspective. Hydrol. Earth Syst. Sci. Discuss. 2016. [CrossRef]

88. Hanel, M.; Rakovec, O.; Markonis, Y.; Maca, P.; Samaniego, L.; Kyselý, J.; Kumar, R. Revisiting the recent European droughts from a long-term perspective. Sci. Rep. 2018, 8,1-11. [CrossRef]

89. Pińskwar, I.; Choryński, A.; Kundzewicz, Z.W. Severe Drought in the Spring of 2020 in Poland-More of the Same? Agronomy 2020, 10, 1646. [CrossRef]

90. Barker, L.J.; Hannaford, J.; Parry, S.; Katie, A.; Smith, K.A.; Tanguy, M.; Prudhomme, C. Historic hydrological droughts 1891-2015: Systematic characterisation for a diverse set of catchments across the UK. Hydrol. Earth Syst. Sci. Discuss. 2019. [CrossRef]

91. Solarczyk, A.; Kubiak-Wójcicka, K. The exhaustion of water resources in the Kuyavian-Pomeranian voivodship in drought condition in 2015. Res. Rural Dev. Water Manag. 2019, 1, 118-125. [CrossRef]

92. Ziernicka-Wojtaszek, A.; Kopcińska, J. Variation in Atmospheric Precipitation in Poland in the Years 2001-2018. Atmosphere 2020, 11, 794. [CrossRef]

93. Wachowiak, G. Wpływ zrzutów wód kopalnianych na wielkość przepływów wody w rzekach w początkowym okresie odwadniania odkrywki “Tomisławice” KWB “Konin”. Górnictwo i Geoinżynieria 2011, 35, 153-166.

94. Bewick, V.; Cheek, L.; Ball, J. Statistics review 7: Correlation and regression. Crit. Care 2003, 7, 451-459. [CrossRef] [PubMed]

95. Salimi, H.; Asadi, E.; Darbandi, S. Meteorological and hydrological drought monitoring using several drought indices. Appl. Water Sci. 2021. [CrossRef]

96. El-Afandi, G.; Morsy, M.; Kamel, A. Estimation of Drought Index over the Northern Coast of Egypt. IJSRSET 2016, 2, 335-344. 